PSYCHOLOGY

\title{
THE PSYCHOLOGICAL ROLE OF ETHNIC IDENTITY IN GLOBALIZATION CONDITIONS
}

\author{
Predko Victoriia \\ Ph.D. Student, Taras Shevchenko National University of Kyiv, Kyiv, Ukraine
}

DOI: https://doi.org/10.31435/rsglobal_wos/31032020/7005

\section{ARTICLE INFO}

Received: 22 January 2020

Accepted: 18 March 2020

Published: 31 March 2020

\section{KEYWORDS}

ethnicity, ethnic identity, globalization, ethnic values, ethnic socialization.

\begin{abstract}
The article is devoted to a theoretical analysis of the problem of ethnic identity and its main mechanisms. The driving factor in the life of the ethnic group is its ethnic identity, which is an important component of socialization and a leading factor in the further development of the individual, its productive functioning in society. The article analyzes the main provisions on the definition of ethnic identity. The basic functions and structure of ethnic identity are considered, its psychological role is determined. The process of ethnic identity formation in the times of globalization changes is characterized. Its leading role in sociopsychological adaptation, maintaining the mental health of the individual and maintaining state integrity are determined. The important role of ethnic identity in the formation of ethno-national values that regulate the living space of society is emphasized. The article presents the relationship of ethnic identity with the ethnic mentality of the population.
\end{abstract}

Citation: Predko Victoriia. (2020) The Psychological Role of Ethnic Identity in Globalization Conditions. International Academy Journal Web of Scholar. 3(45). doi: 10.31435/rsglobal_wos/31032020/7005

Copyright: (C) 2020 Predko Victoriia. This is an open-access article distributed under the terms of the Creative Commons Attribution License (CC BY). The use, distribution or reproduction in other forums is permitted, provided the original author(s) or licensor are credited and that the original publication in this journal is cited, in accordance with accepted academic practice. No use, distribution or reproduction is permitted which does not comply with these terms.

Introduction. Globalization processes are constantly affecting our lives, rapidly changing the socio-cultural space. They affect the personal condition of the person and lead to psychological problems. Thus, among the many problems actualized by the processes of globalization, the issue of the ethnical identity crisis is of great importance.

At present, the formation of ethnic identity is significantly complicated by globalization, which is accompanied by the loss of cultural memory, the change of ethnic values, the erosion of the ethno-cultural soil of the people. Thus, in the context of globalization, it becomes increasingly difficult for peoples to retain their originality and identity, and the individual faces alienation loses its sense of community and identity. The disintegration of habitual social ties and instability in society has a negative impact on the mental health of citizens.

Results and discussion. The term "ethnic identity" refers to a form of self-awareness of an individual or group of people based on their sense of belonging to a particular ethnic community. Its basis is the set of anthropological and cultural-symbolic features rooted in historical memory (common origin, language, religion, territory, traditions, customs, etc.). Identification with an ethnic group under certain conditions stimulates the self-organization of the ethnic community on the basis of its ethnic interests and needs, as well as provides self-protection in situations of ethnic tension.

Ethnic Identity is an awareness of the individual of one's identity to a particular ethnic community, the identification of oneself with it. Ethnic identity is the vital core of the individual and the main indicator of socio-psychological equilibrium, contributes to the internal identity of subjects in their perception of the image of the globalized world, a sense of security and resilience, mental development, forms a sense of belonging of an individual being to a particular community [8]. 
L. Nagornaya identifies the following basic functions of ethnic identity:

- cognitive function which contains certain ethnic stereotypes and ideas about the nature of interethnic communication, forms the perception of the outside world, a sense of common citizenship, patriotism, understanding of national interests;

- communicative (integrative) function which provides the appropriate degree of homogeneity and cohesion of society, determines the ways of social interaction between its members and mechanisms of socialization of individuals. At the same time, it is a factor in psychological communicative distance, which determines relationships with other communities and creates universally recognized regulators of intercultural communicative behavior;

- emotional function - forms a sense of community of interests, protection from the blows of fate, involvement in cultural values;

- compensatory function that allows an individual to find in his group emotional protection from unification processes, standardization, depersonalization, formal social roles;

- ideological function that creates a sense of involvement in the historical fate of the group and provides a degree of social consensus;

- instrumental function, the purpose of which is to create a mechanism for consolidating a positive identity in the mind, focusing on the priority of one's own values and traditions over all others, fostering self-esteem [2, p. 55].

Ethnic identity is based on the peculiarities of psychological composition, temperament, ethno-demographic potential of a person. It is closely intertwined with the ethnic metallicity of the population. Mentality is an integral value characteristic of a social community. It is the system of elements of spiritual life and worldview which determines the corresponding stereotypes of behavior, activity, way of life of the group. It includes a set of values, symbolic, conscious or subconscious feelings, perceptions, moods and views. The mentality includes habits, aspirations, symbolism, traditions, intuitive unconscious that exist at the level of unconscious mental processes [4]. The subject of mentalities is not the individual but the society. It is manifested in the verbal language (verbal culture of society)and the language of gestures, behavior, customs, traditions and beliefs. The concept of mentality allows a person to combine analytical thinking, developed forms of consciousness with semi-conscious cultural codes. Mentality connects numerous oppositions such as natural and cultural ones, emotional and mental ones, irrational and rational ones, individual and social ones. In modern humanitarian knowledge, the notion of mentality has become widespread and it is used not only to refer to certain cultural stereotypes typical to large social groups or to characterize the spiritual mood of the whole society but also to interpret the way of thinking, beliefs, a small group of people [6].

Ethnic identity arises as the driving and controlling force of national life and development. It reflects the integrated unity of functioning of a set of socio-psychological phenomena, processes, concepts, meanings, senses, beliefs, traditions, customs, stereotypes, value orientations, attitudes that influence the behavior and activity of the people, their socio-psychological state [5]. It is a leading element in population development because it helps to preserve statehood creating favourable conditions for its development. Positively formed ethnic identity is a necessary condition for the development of patriotic feelings, the manifestation of a sense of national dignity, high ethnic selfesteem and spiritual affinity with the state. A sense of belonging to a community that affords ethnic identity performs important social and psychological functions, first and foremost providing subordination of the individual to a social group and, at the same time, group protection.

Ethnic identity gives the person a sense of stability and security in an unusual social environment, migration while interacting with representatives of another ethnic group. To a large extent, ethnic identity influences one's mental health. The concept of "mental health" is often defined as a state of mental wellbeing, balance, comfort, harmony of internal experiences. A mentally healthy person is integrated, consolidated, balanced. Being in a state of uncertainty leads to the destruction of mental health, anxiety, worry [7]. Ethnic identity contributes to the socio-psychological adaptation in modern society, provides internal stability and coherence, performs a psychological-compensatory role, consolidates and protects personality. Positive perception of one's ethnicity, sense of dignity, desire to be a member of a community give one a sense of psychological security and stability. Conversely, the presence of negative feelings related to ethnicity, the crisis of ethnic identity activates the mechanisms of social and psychological protection and leads to maladaptation. Thus, the formation and support of ethnic identity is a necessary condition for maintaining the mental health of the individual and its harmonious development. 
Ethnic identity not only expresses an individual's awareness and experience of belonging to a particular ethnic community but also assures a real existence and functioning as a member of an ethnic group, that is, in accordance with the lifestyle adopted in that group. Thus, ethnic identity influences the formation of ethnic values which are part of the worldview of the community and act as a system that provides a common life, play a leading role in its integrating, socializing and communicative principles. Since the basis of the existence of any society is the corresponding value system as a kind of moral censor of the social system, ethnic values are an integral component of consciousness and are leading socio-cultural guidelines that determine the spiritual development of the individual and society as a whole. They are based on self-restraint and overcoming immediate internal impulses, restriction of their personal, individual goals of the person or generally abandoning them in favour of the social system.

It is well known that each society has its own specific hierarchy of values, which acts as a connecting link between individual and social life. According to E. Durkheim, society is the creator and repository of all values and each society has a set of very different, sometimes completely opposite value ideas and only one defined axiological model forms a specific type of social relations in a given society. Such a model reflects the goals and orientation of social progress and forms its internal basis [1]. Ethnic values form the psychological foundation of the ethno-national community, regulate its living space, give meaning to actions and orient in the results of society. To a large extent, ethnic values are linked to the socio-cultural context and arise as an element of the general ethno-national field, set the strategy for the development of society and the activities of its subjects. That is, a person does not objectify but subjectifies the external reality, appropriates it and experiences as personal, gives it humanistic meanings and is aware of its identity with itself [3, p. 401]. Ethnic values play a key role in the development of the ethno-national community, namely in the formation of the spiritual and value core of ethno-national consciousness, which is connected with the understanding of society's norms of activity in the context of setting a common goal and solving various problems. The state falls into decay when its representatives begin to adhere to different value orientations. Therefore, a common, integral value system acts as a necessary element in the development of an ethno-national community which are a leading component of the mechanism of self-organization of society. Thus, ethnic identity, representing the ethnic values of the people, acts as an intrapsychic link that connects the individual with the group, determines common, coordinated orientations in behavior. It promotes the development of ethno-national self-awareness, the formation of a social ideal and the universally recognized ideology of state-building. It is a significant factor in the constructive life of the ethnic community and an important prerequisite for the harmonious development of each member of community.

Positive ethnic identity is the basis of ethnic tolerance. Normally for group consciousness, there is a close internal connection between positive group identity and group tolerance. In adverse circumstances, this relationship may disintegrate or take on the opposite meaning. Ethnic tolerance is a systematic set of psychological attitudes, feelings, a certain set of knowledge and social and legal norms, as well as worldview and behavioral orientations that suggest a tolerant or acceptable attitude of representatives of one ethnic group (in particular, on a personal level) to other inoethnic phenomena (such as language, culture, customs, behaviors, etc. ) or representatives of other ethnic groups. It gives the individual the opportunity to interact freely and successfully with other people in a multicultural society.

The need for psychological unity with an ethnic group in different people manifests itself in different ways. The depth of assimilation processes, as well as the situations of uncertainty, provoke changes in ethnic code: subjective self-identification often does not coincide with ethnic origin. The process of comparing an individual with a particular community can be realized or not, be unambiguous or ambiguous. Very common as a result of migration and the development of the information network is an ethnomarginal type of self-identification that lacks a focus on affinity with a particular culture. The cosmopolitan type in its extreme manifestations generally considers ethnic criteria as a sign of provincialism and focuses solely on universal values. That is why it is worth paying attention to the process of formation of ethnic identity in a timely manner, contributing to the development of its positive level. An important role in the formation of ethnic identity belongs to ethnic socialization. Ethnic socialization is a process of assimilation by an individual of the system of values, norms and forms of behavior inherent in an ethnic group. It is the internalization of the peculiarities of the social existence of an ethnic group which transforms the individual into a representative of a particular ethnic group. It continues throughout life, covers all stages of human development and manifests itself in the acquisition of the social experience of the ethnic group that helps to function in the ethnic environment. Thus, the process of determining an 
individual's ethnic identity is not rigidly determined. It occurs through multi-level reproduction by the individual (through family, ethnic organizations, educational societies, cultural activities) of the characteristics of his own ethnic identity, group core values and emotional and volitional aspirations, as well as ethnic symbols and shrines. The result of this process is a complex interweaving of innate and acquired traits, rational and irrational ideas, and real actual interests.

Conclusions. Consequently, in the context of globalization, ethno-national identity plays a significant role, which is a key element of the mental health of society. Low levels of ethnic identity lead to the destruction of personal space, causing deprivation and conflict, internal tension, and mental health disorders. It arises a condition for preserving the ethnic community as a whole and unique organism, contributes to the psychological adaptation of each of its representatives. It makes it possible to feel like an accomplice in world socio-historical processes, linking the previous achievements of the ethnos with modern and prognostic ones, which has a certain psychotherapeutic effect of stability. It defines the connection of the individual with the community, acting as a fixed nucleus through which the internal system of an attitude of the personality towards the world and to itself, a system of self-control and self-orientation is formed.

\section{REFERENCES}

1. Dudkevych T. (2018) Nacional`no-kul`turna identy`chnist` yak chy`nny`k psy`xichnogo zdorov’ya osoby`stosti. [National-cultural identity as a factor of mental health of the individual.]. Abstracts of Papers: Formuvannya nacional’no-kul`turnoyi identy`chnosti osoby`stosti u vy`kly`kax chasu: zbirny`k materialiv Vseukrayins`kogo kruglogo stolu (do 100-richchya vid zasnuvannya Kam’yanecz'-Podil``kogo nacional'nogo universy tetu imeni Ivana Ogiyenka). (pp. 53-56). Kamianets-Podilskyi. [in Ukrainian].

2. Durkheim E. (1991) Cennostnye i "real'nye" suzhdenija [Value and "real" judgments]. Sociologicheskie issledovanija, 2, 17-26. [in Russian].

3. Nagorna L. (2002) Nacional’na identy`chnist` v Ukrayini [National identity in Ukraine]. Kyiv. [in Ukrainian].

4. Nakonechny`j V. M. (2011) Svitove ukrayinstvo V suchasny`x globalizacijny`x procesax. [World Ukrainianness in modern globalization processes.] Problemy` mizhnarodny`x vidnosy`n: zb. nauk.pracz. (2). 164-179. [in Ukrainian].

5. Skotny`j V. G. (2005) Filosofiya: Istory`chny`j i sy`stematy`chny`j kurs. [Philosophy: A history and systematic course.]. Kyiv: Znannya Ukrayiny. [in Ukrainian].

6. Uvarova T. I. (2012) Terminologichna problematy`ka kategoriyi mental`nosti v kul turologiyi. [Terminological issues of the category of mentality in cultural studies] Naukovi zapy`sky`. Seriya "Kul turologiya", 9. 3-13. [in Ukrainian].

7. Varij M. J. (2009) Zagal`na psy`xologiya: pidruchny`k. [General psychology: textbook] Kyiv: Centr uchbovoyi literatury. [in Ukrainian].

8. Zabely`na N.A. (2003) Mentalitet i mental'nost'. [Mentality] Teorija jazyka i mezhkul'turnaja kommunikacija. 21-28. [in Russian]. 